\title{
Foraging strategies of shy albatross Thalassarche cauta breeding at Albatross Island, Tasmania, Australia
}

\author{
April Hedd $^{1, *}$, Rosemary Gales ${ }^{2}$, Nigel Brothers ${ }^{2}$ \\ ${ }^{1}$ School of Zoology, GPO Box 252-05, University of Tasmania, Hobart, Tasmania 7001, Australia \\ ${ }^{2}$ Parks and Wildlife Service, Department of Primary Industry, Water and Environment, GPO Box 44A, Hobart, \\ Tasmania 7001, Australia
}

\begin{abstract}
The foraging zones and behaviour of shy albatross Thalassarche cauta were studied at Albatross Island, Tasmania, Australia, during the 1995/96 and 1996/97 breeding seasons, using a combination of archival recorders and satellite telemetry. Birds foraged exclusively in the neritic zone, at a maximum distance of $200 \mathrm{~km}$ from the colony, making wide use of continental shelf waters off northwest Tasmania. The duration of foraging trips, the distances traveled and the activity ranges of the birds (i.e. $95 \%$ isopleths from Kernel home range analyses) were greatest during incubation $\left(2.8 \mathrm{~d}, 754 \mathrm{~km}, 24667 \mathrm{~km}^{2}\right)$, least during chick-brood $\left(1.1 \mathrm{~d}, 273 \mathrm{~km}, 19067 \mathrm{~km}^{2}\right)$, and intermediate during early chick-rearing $\left(1.8 \mathrm{~d}, 426 \mathrm{~km}, 19400 \mathrm{~km}^{2}\right)$. At the population level, the foraging zones of the birds (i.e. the $50 \%$ home range isopleths) were highly consistent between years, overlapping by $43 \%$ during both the incubation and chick-brooding stages across 3 breeding seasons. Overall, the foraging zones of males and females were similar in both size and location. Individual birds did not return to the same locations to feed from 1 trip to the next; however, their foraging was not random. On successive trips birds maintained a constant heading from the colony, repeatedly searching the same broad patches of ocean, a degree of site fidelity maintained within a single breeding stage. They flew for $72 \%$ of the daytime and $39 \%$ of the night, and their rate of travel was significantly higher during the day. Combined with a diet predominated by prey found at or near the surface during the day, these data suggest that shy albatross are largely diurnal feeders. Nocturnal activity was strongly influenced by moon phase, with increased time spent flying and increased flight speed during full moon. Consistent traveling speeds, foraging trip durations and foraging locations across years suggest relatively stable prey availability and/or accessibility for shy albatross breeding off the northwest coast of Tasmania.
\end{abstract}

KEY WORDS: Shy albatross $\cdot$ Satellite tracking $\cdot$ Foraging $\cdot$ Site fidelity $\cdot$ Activity patterns

\section{INTRODUCTION}

Knowledge of the distribution and activity patterns of birds at sea is fundamental to understanding predator-environment (e.g. Guinet et al. 1997, Hull et al.

\footnotetext{
*Present address: 4 Hammond Estates, Portugal Cove-St. Phillips, Newfoundland A0A 3K0, Canada.

E-mail: ahedd@attcanada.net
}

1997, Prince et al. 1998, Waugh et al. 1999) and predator-prey (e.g. Weimerskirch et al. 1994, 1997c, Bost et al. 1997, Garthe et al. 1999) interactions. The miniaturization of satellite transmitters over the past $10 \mathrm{yr}$, and their increased use on albatrosses and penguins, has revolutionized our capacity to understand habitat use by marine birds. For albatrosses, these data have resulted in descriptions of foraging strategies (see Weimerskirch 1998) that represent the diversity of 
ways that birds trade off the distribution of exploitable resources, which are often markedly influenced by the configuration and dynamics of the physical environment, with their commitments at the nest. Albatrosses and other seabirds spend much of their foraging time in areas of enhanced productivity, often in association with continental shelves, shelf slopes or frontal zones (Weimerskirch et al. 1993, Hull et al. 1997, Brothers et al. 1998, Prince et al. 1998, Waugh et al. 1999). During the brooding period, for example, wandering albatross Diomedea exulans from the Crozet Islands rely on resources concentrated over the shelf break (Weimerskirch et al. 1993, 1997a), while when raising chicks, grey-headed albatross Thalassarche chrysostoma from both South Georgia and Campbell Island forage in association with the Polar Frontal Zone (PFZ; Prince et al. 1998, Waugh et al. 1999). Given the diversity of marine habitats exploited, in conjunction with the birds' changing commitments at the nest, it is perhaps not surprising that foraging strategies can vary through time, both for a single species across the breeding season, as well as within and between species breeding at different sites (Weimerskirch et al. 1993, Weimerskirch 1998, Waugh et al. 1999).

Earlier studies of shy albatross Thalassarche cauta at Albatross Island, Tasmania indicated that, while breeding, birds foraged exclusively over the southeast Australian continental shelf within $200 \mathrm{~km}$ of the colony (Brothers et al. 1998); nonparametric fixed Kernel Home Range Analyses, incorporating $95 \%$ of locations, were used to characterize both the location and the size of areas used by birds during the incubation and chick-brooding periods in 1993/94. Data from 1995/96 and 1996/97 are presented here and compared with data from 1993/94 to further investigate habitat use by this population. Specifically, we quantify the degree of spatial consistency in foraging zone use at a number of levels, ranging from between-year comparisons of population-level foraging zones to investigations of the consistency in foraging zone use for individual birds. These issues have been examined for relatively few seabird species (but see Weimerskirch et al. 1997b), yet they are central to understanding foraging strategies and the environmental factors that influence them. Such studies have additional relevance for Procellariiformes, particularly albatrosses, both for understanding the dynamics of their interactions with, and their vulnerability to, incidental capture in longline fisheries (cf. Brothers et al. 1998). During the 1996/97 season archival wet-dry activity recorders were deployed to collect fine-scale behavioural information on the bird's activity patterns at sea and these data are presented here to augment interpretation of the satellite locations. Sea surface temperatures (SST) of the foraging zones are also described.

\section{MATERIALS AND METHODS}

Species and study sites. Shy albatross breed annually at 3 sites in Australia; 5000 pairs at Albatross Island $\left(40.375^{\circ} \mathrm{S}, 144.656^{\circ} \mathrm{E}\right)$ in western Bass Strait, and 250 and 7000 pairs off the south coast of Tasmania at Pedra Branca $\left(43.867^{\circ} \mathrm{S}, 146.967^{\circ} \mathrm{E}\right)$ and Mewstone $\left(43.742^{\circ} \mathrm{S}, 146.375^{\circ} \mathrm{E}\right)$ respectively (Fig. 1). This study was conducted at Albatross Island, where birds lay their eggs in September and hatch chicks in December (N.B. unpubl. data). During the $10 \mathrm{wk}$ incubation and 3 to $4 \mathrm{wk}$ brooding periods, parents alternate shifts on the nest with foraging trips at sea. Chicks are fed by both parents for a further 14 to $16 \mathrm{wk}$, and they typically fledge in April. After departing the colonies, young birds spend at least the next $2 \mathrm{yr}$ at sea (N.B. unpubl. data).

Field protocol. Satellite telemetry was used to study the distribution and movements of birds at sea during incubation (September/October) and chick-brooding (December) in 1995/96 and 1996/97, and during postbrood chick-rearing (January/February) in 1996/97. Satellite packs were deployed only at nest changeovers and always to the bird about to commence a foraging trip. The sex of study birds was determined from morphometric measures (Hedd et al. 1998), and birds were banded with a stainless steel band on their left leg, a darvic colour band on their right leg, and colourmarked with an individually identifiable pattern on the breast using Dulux hi-gloss enamel spray paint. Platform terminal transmitters (PTTs) (Telonics ST10, 85g, $9.0 \times 4.2 \times 1.7 \mathrm{~cm}, 1.9$ to $2.4 \%$ of adult body mass; and,

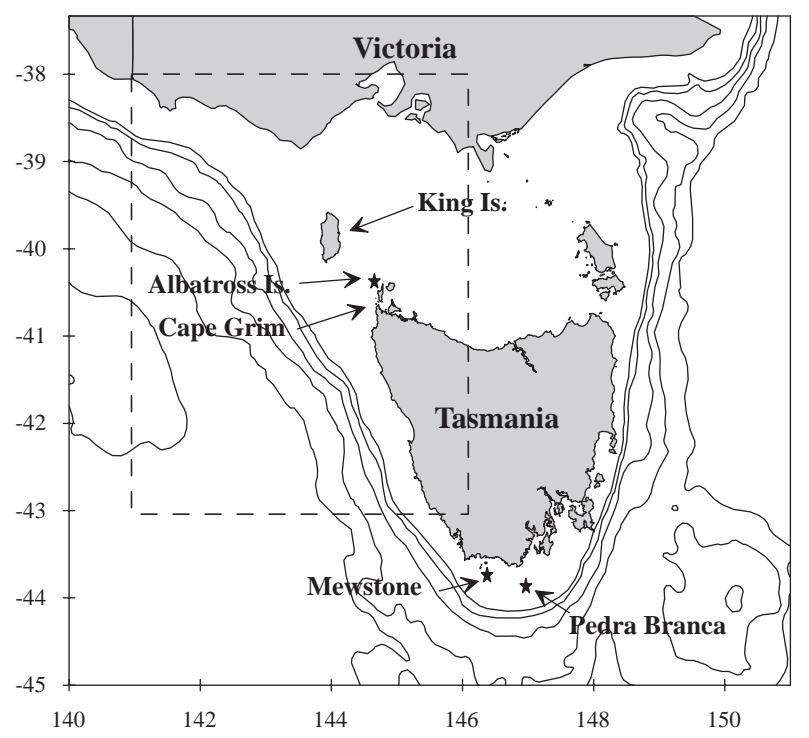

Fig. 1. Map of study area. Box (dashed line) enlarged in subsequent figures 
Toyocom $2038 \mathrm{C}, 120 \mathrm{~g}, 13.0 \times 3.5 \times 1.8 \mathrm{~cm}, 2.6$ to $3.4 \%$ of adult body mass) were attached directly to feathers in the centre of the birds' backs using TESA ${ }^{\oplus}$ tape. The PTTs ran continually, pulsing every 60 or $90 \mathrm{~s}$.

Trip durations of birds fitted with transmitters were calculated primarily from visual attendance checks made at the colony every 2 to $3 \mathrm{~h}$ during daylight. Trips were regarded as having commenced either when birds were first observed absent from the nest site, or when consistent satellite locations were obtained at sea, and they ended when birds were subsequently observed at the nest.

All previous attempts to study the foraging distribution of shy albatross during post-brood chick-rearing (March/April) have resulted in nest desertion (see Brothers et al. 1998). In an attempt both to increase information about this period and to minimize disturbance, we deployed 2 transmitters within days of the end of the brooding period (January) in 1997 and within hours of our departure from the Island. Trip durations for these birds were calculated from the midpoint of locations as birds headed towards and then away from the Island. As birds return ashore only briefly to feed chicks at this time of year, with visits lasting $\sim 5$ to $10 \mathrm{~min}$, satellite locations when they were on the Island were rarely obtained.

Management of the satellite tracking data. ARGOS system location files were filtered, based upon maximum observed flight speeds, and processed as detailed in Brothers et al. (1998). Foraging trips were described according to: (1) their maximum foraging range (i.e. the distance from the colony to the furthest location afield), and (2) the total distance traveled. When data for individual birds were available on more than 1 foraging trip, mean foraging trip characteristics were used (duration, range and distance) for comparison between breeding stages and years, in order to overcome problems of statistical independence. The 'directness' of travel was estimated by calculating the maximum foraging range as a percentage of the total distance traveled. This estimate was compared across stages of the breeding season using nested ANOVA.

Characterization of the foraging zones and time allocation along foraging trips. 'Fixed kernel home range analyses', with the smoothing factor chosen via least squares cross validation, were conducted using RangesV Software (R. Kenward, Institute of Terrestrial Ecology, Dorset, UK) to determine both the activity ranges of shy albatross (i.e. areas incorporating $95 \%$ of locations; see Brothers et al. 1998) and the concentrations of locations that presumably represented their foraging zones (i.e. incorporating $50 \%$ of locations; see Wood et al. 2000). Overlap analyses in RangesV were used to quantitatively compare area use at the popula- tion level both between and within years, as well as to compare patterns of area use for individual birds. As reported in Brothers et al. (1998) 50 locations were required to conduct analyses at the population level, while for individual-level comparisons, 20 locations were sufficient. Data from the 1993/94 season, previously presented by Brothers et al. (1998), were included here to allow for more extensive between-year comparisons.

We were also interested in whether individual birds foraged in similar areas on successive trips to sea. As foraging trips are short ( $3 \mathrm{~d}$ during incubation and $1 \mathrm{~d}$ during brood; Hedd 1998), the number of locations obtained was often inadequate for application of home range techniques. Instead, a series of custom programs (see Bost et al. 1997) was used to quantify and compare area use on successive trips. Interpolating from the satellite locations, the bird's position was estimated every $10 \mathrm{~min}$, assuming that traveling speed was constant and direction was a straight line between successive locations (Weavers 1992). A matrix with grid size defined by the user was then imposed over the locations, enabling calculation of the amount of time spent in each block. To separate foraging areas from transit areas (i.e. where birds simply traveled through) the median time spent per block was calculated and used as a threshold value. Areas where birds spent more than the threshold time were regarded as lying within their foraging zones. This interpretation is based upon a study of king penguins Aptenodytes patagonicus (Bost et al. 1997) in the absence of validation with albatrosses.

Comparison of area use across foraging trips was conducted only when 5 or more locations were received at sea because a great degree of interpolation was required. Overlap between trips was calculated only within the foraging zones, and presented as means (i.e. the mean overlap of trip 1 on trip 2, and of trip 2 on trip 1). Overlap analyses were conducted at 2 spatial scales: (1) a fine scale, with $0.05^{\circ} \times 0.05^{\circ}$ $(\sim 5 \mathrm{~km} \times 5 \mathrm{~km})$ grid cells, approaching the accuracy of the satellite locations themselves (Brothers et al. 1998); and (2) a broad scale, with $0.25^{\circ} \times 0.25^{\circ}(\sim 25 \mathrm{~km} \times$ $25 \mathrm{~km})$ grid cells. The fine scale assessed whether birds returned to the same location to feed from one trip to the next, as might be expected if they used bathymetric features such as sea mounts or shelf breaks as cues. The broad scale assessed whether foraging was random (i.e. in any direction from the colony), and whether the birds foraged in the same general, but not necessarily specific, areas between trips. Birds might consistently favour broad areas, but not specific, smaller areas, when feeding on mobile prey for instance. The spatial resolution of the broad scale was ultimately limited by the size at which mean- 
ingful comparisons could be made during chick-brood, when birds feed within $100 \mathrm{~km}$ of the colony (Brothers et al. 1998).

Fine-scale behaviour: rates of travel and patterns of activity at sea. Instantaneous rates of travel (i.e. between successive locations) were log-transformed due to lack of normality and compared across stages of the breeding season, and according to time of day, using nested ANOVA. Locations were not equally probable during each hour, because of the limitations of satellite coverage, and relatively few locations were recorded from 09:00 to 13:00 h local time (see also Brothers et al. 1998). The time between locations influenced the estimated rates of travel, with increasing underestimates resulting from locations spaced further apart $\left(F_{3,2020}=62.7, \mathrm{p}<0.001\right)$. Specifically, estimates from locations spaced by $<2 \mathrm{~h}\left(15.0 \pm 14.33 \mathrm{~km} \mathrm{~h}^{-1}\right.$, $\mathrm{n}=$ 1237 ) were significantly greater than those at all other temporal resolutions $\left(2\right.$ to $4 \mathrm{~h}, 9.6 \pm 7.48 \mathrm{~km} \mathrm{~h}^{-1}, \mathrm{n}=$ $576 ; 4$ to $6 \mathrm{~h}, 6.6 \pm 5.27 \mathrm{~km} \mathrm{~h}^{-1}, \mathrm{n}=100 ;>6 \mathrm{~h}, 6.9 \pm$ $5.25 \mathrm{~km} \mathrm{~h}^{-1}, \mathrm{n}=111$; Tukey's HSD $\left.\mathrm{p}<0.05\right)$. Statistical comparison of instantaneous rates of travel were limited because of this to locations spaced by $<2 \mathrm{~h}$ ( $\mathrm{n}=$ 1237).

Total distances traveled during daytime and nightime were calculated for each full day that the birds spent at sea. Daytime commenced in the morning with nautical twilight (i.e. the instant when the sun is $12^{\circ}$ below the horizon) and continued until nautical twilight in the evening. Nighttime was the intervening period. As the number of daylight hours and the precise time of locations varied between days, the distances covered were corrected for time, providing average rates of travel across the full day and night. Average rates of travel were compared across time of day using a Wilcoxon matched pairs test, and for breeding stage and year using nested ANOVA. Rates of travel at night were compared, using nested ANOVA, across 3 lunar phases: full moon and new moon (including $3 \mathrm{~d}$ either side), and the remaining 2 weeks when the moon was in quarter or 3-quarter phase.

Tubular shaped wet/dry activity recorders sewn into padded Velcro bands $(16 \mathrm{~g}, 4.4 \times 1.7 \mathrm{~cm}, 0.4$ to $0.5 \%$ adult body mass; FSI, Cambridge, UK) were deployed during incubation and chick-brood in 1996/97. Recorders were placed on the bird's right leg, archiving information once every $16 \mathrm{~s}$. The following information was obtained for 1 to 6 foraging trips for each bird: (1) the proportion of time spent flying and sitting on the water during the day and night; (2) the landing frequency $\left(\mathrm{h}^{-1}\right)$; and (3) the duration of each wet and dry bout. Bouts commenced each time a state change was recorded.

Differences in the proportion of time spent on the water during the day and night were assessed using repeated measures ANOVA, and stage differences were assessed using nested ANOVA. Nocturnal activity was also assessed relative to: (1) moon phase, using 1-way ANOVA; and (2) wind strength, using Spear-

Table 1. Thalassarche cauta. Deployment schedules of satellite transmitters and foraging trip characteristics for shy albatross during 1995/96 and 1996/97. Values for each breeding stage (mean \pm SD) in bold

\begin{tabular}{|c|c|c|c|c|c|c|c|}
\hline $\begin{array}{l}\text { Breeding stage } \\
\text { (months) }\end{array}$ & Year & $\begin{array}{l}\text { No. of individual }{ }^{\mathrm{a}} \\
\text { (total trips) }^{\text {a }}\end{array}$ & $\begin{array}{l}\text { No. } \\
\text { of } \operatorname{txs}^{b}\end{array}$ & $\begin{array}{l}\text { No. of filtered } \\
\text { locations at } \\
\text { sea }\end{array}$ & $\begin{array}{c}\text { Foraging trip } \\
\text { duration (d) } \\
\text { (range) }\end{array}$ & $\begin{array}{l}\text { Foraging } \\
\text { range }(\mathrm{km}) \\
\text { (range) }\end{array}$ & $\begin{array}{c}\text { Distance } \\
\text { covered }(\mathrm{km}) \\
\text { (range) }\end{array}$ \\
\hline \multirow[t]{3}{*}{$\begin{array}{l}\text { Incubation } \\
\text { (Sep/Oct) }\end{array}$} & $1995 / 96$ & $4(15)$ & 3 & 318 & $\begin{array}{r}2.4 \pm 0.73 \\
(0.7-3.7)\end{array}$ & $\begin{array}{r}173 \pm 48.7 \\
(59-297)\end{array}$ & $\begin{array}{r}703 \pm 207.1 \\
(211-1334)\end{array}$ \\
\hline & 1996/97 & $3(9)$ & 3 & $290^{\mathrm{c}}$ & $\begin{array}{r}3.5 \pm 0.31 \\
(1.7-4.5)\end{array}$ & $\begin{array}{r}189 \pm 17.5 \\
(86-271)\end{array}$ & $\begin{array}{r}823 \pm 95.6 \\
(314-1006)\end{array}$ \\
\hline & Total & $6(24)$ & & 605 & $2.8 \pm 0.72$ & $180 \pm 36.9$ & $754 \pm 169.1$ \\
\hline \multirow[t]{3}{*}{$\begin{array}{l}\text { Chick-brooding } \\
\text { (Dec) }\end{array}$} & $1995 / 96$ & $6(44)^{\mathrm{d}}$ & 4 & 394 & $\begin{array}{r}1.2 \pm 0.28 \\
(0.3-2.5)\end{array}$ & $\begin{array}{l}96 \pm 26.0 \\
(12-208)\end{array}$ & $\begin{array}{r}267 \pm 70.9 \\
(24-690)\end{array}$ \\
\hline & $1996 / 97$ & $10(46)$ & 6 & 394 & $\begin{array}{r}1.0 \pm 0.35 \\
(0.5-1.9)\end{array}$ & $\begin{array}{r}103 \pm 27.1 \\
(19-230)\end{array}$ & $\begin{array}{r}276 \pm 53.2 \\
(48-576)\end{array}$ \\
\hline & Total & $15(90)$ & & 788 & $1.1 \pm 0.23$ & $100 \pm 26.0$ & $273 \pm 58.3$ \\
\hline \multirow[t]{3}{*}{$\begin{array}{l}\text { Early chick-rearing } \\
\text { (Jan/Feb) }\end{array}$} & $1995 / 96$ & $1(2)$ & 1 & 23 & $\begin{array}{r}2.0 \pm 0.91 \\
(0.3-2.0)\end{array}$ & $\begin{array}{r}100 \pm 90.7 \\
(31-203)\end{array}$ & $\begin{array}{r}297 \pm 346.8 \\
(65-696)\end{array}$ \\
\hline & $1996 / 97$ & $4(25)$ & 4 & $593^{e}$ & $\begin{array}{r}2.1 \pm 0.47 \\
(0.6-6.6)\end{array}$ & $\begin{array}{r}124 \pm 12.8 \\
(44-230)\end{array}$ & $\begin{array}{r}459 \pm 159.3 \\
(117-1011)\end{array}$ \\
\hline & Total & $5(27)$ & & 616 & $1.8 \pm 0.62$ & $119 \pm 15.5$ & $426 \pm 155.6$ \\
\hline Totals & & $21(141)$ & & 2012 & & & \\
\hline
\end{tabular}


man rank regression analyses. For the latter analyses, bird activity was summarized in blocks of $3 \mathrm{~h}$ to correspond with wind readings, and relationships were assessed separately according to time of day and breeding stage. Wind data were collected from automatic weather stations and obtained from the Bureau of Meteorology, Hobart, Tasmania. Being closest to bird activity at sea, wind data from King Island were used during incubation, while those from the station at Cape Grim were used during chick-brood (Fig. 1).

Sea-surface temperature in the foraging zones. Satellite-derived estimates of SST were obtained at $3.3 \times 3.3 \mathrm{~km}$ resolution for the southeast Australian region once every $10 \mathrm{~d}$ during the tracking sessions. Data were weekly compilations of daily or twice daily passes, overlaid and median filtered by CSIRO's Division of Remote Sensing in Hobart, Tasmania.

\section{RESULTS}

\section{Sample size and general description of the data}

During the 1995/96 and 1996/97 breeding seasons 21 individuals were tracked by satellite for 141 foraging trips (Table 1). While birds were at sea 2190 locations were received, and $91.9 \%$ (2012) remained after filtering. For each bird each day, $8 \pm 1.9$ (range 3 to 12) locations were received $(n=330 \mathrm{~d})$.

\section{Effect of carrying satellite packs}

Except for incubation in 1995/96, birds that carried satellite packs had significantly longer foraging trips than those that carried lighter-weight, leg-mounted VHF transmitters $(20 \mathrm{~g}, 0.4$ to $0.6 \%$ body mass; Table 2). Despite the extended trip durations, birds carrying packs during incubation and chick-brood continued to breed. In contrast, while birds equipped with satellite packs past the end of brood in January 1997 did initially feed their chicks, they abandoned the breeding attempt after 21 and $28 \mathrm{~d}$. Their chicks were nonetheless healthy at banding 9 wk later, and the adults themselves were re-sighted in the colony the subsequent winter.

\section{Foraging trip characteristics}

The duration of foraging trips and the distances traveled by birds are summarized in Table 1 according to breeding stage and year. As there were no differences between years in trip duration, maximum foraging range or the total distances covered, during either incubation $\left(F_{1,5}=5.2, \mathrm{p}>0.05 ; F_{1,5}=0.3, \mathrm{p}>0.05 ; F_{1,5}=0.8, \mathrm{p}>0.05\right.$ respectively) or brood $\left(F_{1,14}=0.1, \mathrm{p}>0.05 ; F_{1,14}=0.6, \mathrm{p}>\right.$ $0.05 ; F_{1,14}=0.8, \mathrm{p}>0.05$ respectively), data were pooled across years to evaluate differences between the breeding stages. Trip durations, maximum foraging ranges and the overall distances birds traveled varied with breeding stage $\left(F_{2,25}=30.9, \mathrm{p}<0.001 ; F_{2,25}=20.1, \mathrm{p}<\right.$ $0.001 ; F_{2,25}=44.2, \mathrm{p}<0.001$ respectively; Table 1$)$, with highest values recorded for all parameters during incubation $(2.8 \pm 0.72 \mathrm{~d}, 180 \pm 36.9 \mathrm{~km}$ and $754 \pm 169.1 \mathrm{~km}$ respectively; Tukey's HSD, $\mathrm{p}<0.05)$. Trips were shortest during the brooding period $(1.1 \pm 0.23 \mathrm{~d})$, when birds foraged within $100 \pm 26.0 \mathrm{~km}$ of the Island. Trip durations, maximum foraging ranges and the overall distances traveled were similar for males and females during the brooding period, and this was the only stage where there were sufficient numbers of individuals for such comparisons.

Foraging trip duration was positively related to both the total distance traveled and to the maximum foraging range (Spearman's rank correlation coefficient $\mathrm{R}_{\mathrm{S}}=$ $0.88, \mathrm{p}<0.001 ; \mathrm{R}_{\mathrm{S}}=0.77, \mathrm{p}<0.001$ respectively; see also Brothers et al. 1998). The maximum foraging range constituted $37.7 \pm 9.0 \%(\mathrm{n}=95)$ of the total distance traveled during brood, higher than at any other stage of the breeding season (incubation, $25.3 \pm 6.9 \%, \mathrm{n}=24$; chickrearing, $30.9 \pm 11.3 \%, \mathrm{n}=23 ; F_{2,19}=14.5, \mathrm{p}<0.001$; Tukey's HSD p < 0.001), suggesting that brooding birds returned to the colony more directly after finding food.

Table 2. Thalassarche cauta. Comparison of foraging trip durations for birds carrying satellite versus leg-mounted VHF transmitters. Data: d, mean \pm SD (n)

\begin{tabular}{|c|c|c|c|c|}
\hline \multirow[t]{2}{*}{ Breeding stage } & \multirow[t]{2}{*}{ Year } & \multicolumn{2}{|c|}{ Transmitter type } & \multirow{2}{*}{$\begin{array}{c}t \text {-test } \\
t, \mathrm{p}\end{array}$} \\
\hline & & Satellite & VHF & \\
\hline Incubation & $\begin{array}{l}1995 / 96 \\
1996 / 97\end{array}$ & $\begin{array}{l}2.4 \pm 0.73(4) \\
3.5 \pm 0.31(3)\end{array}$ & $\begin{array}{l}1.7 \pm 0.82(10) \\
2.3 \pm 0.73(20)\end{array}$ & $\begin{array}{l}-1.48,0.166 \\
-2.65,0.015\end{array}$ \\
\hline Chick-brooding & $\begin{array}{l}1995 / 96 \\
1996 / 97\end{array}$ & $\begin{array}{l}1.2 \pm 0.28(6) \\
1.1 \pm 0.20(10)\end{array}$ & $\begin{array}{l}0.9 \pm 0.21(16) \\
0.9 \pm 0.12(20)\end{array}$ & $\begin{array}{l}-2.25,0.036 \\
-4.58,0.000\end{array}$ \\
\hline Early chick-rearing & $1996 / 97$ & $2.3 \pm 0.57(2)$ & $1.0 \pm 0.28(20)$ & $-5.90,0.000$ \\
\hline
\end{tabular}


Incubation

$1993 / 94$

A.

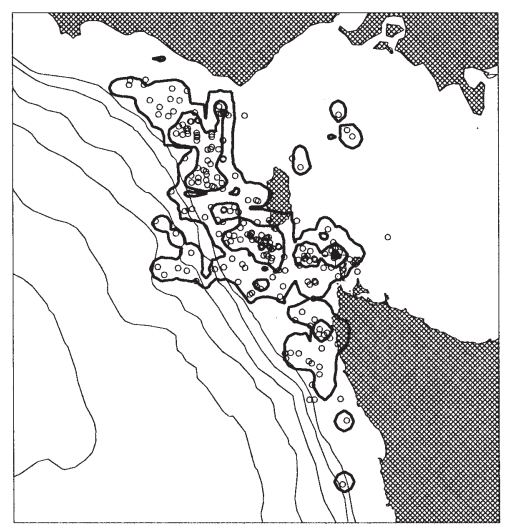

B.

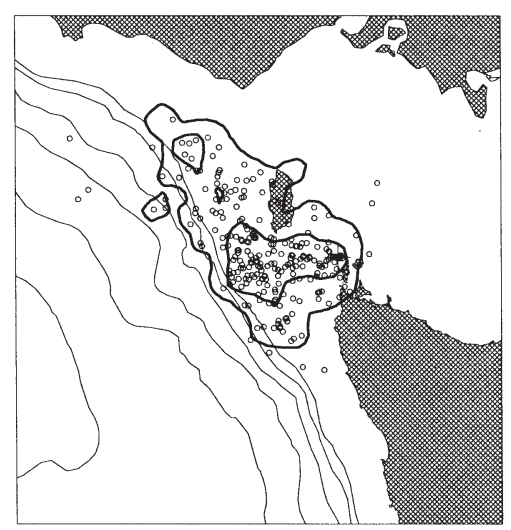

1996/97

C.

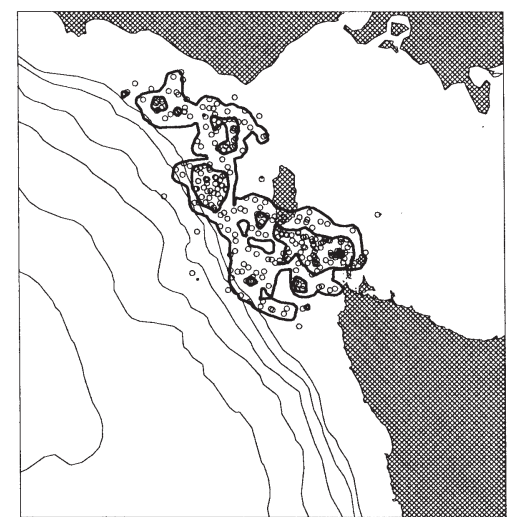

Chick-brood

D.

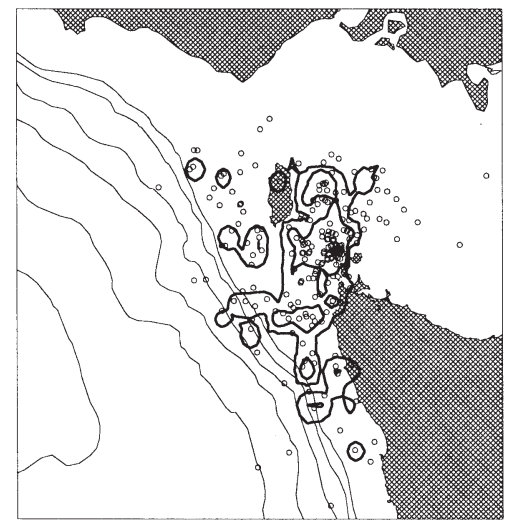

E.

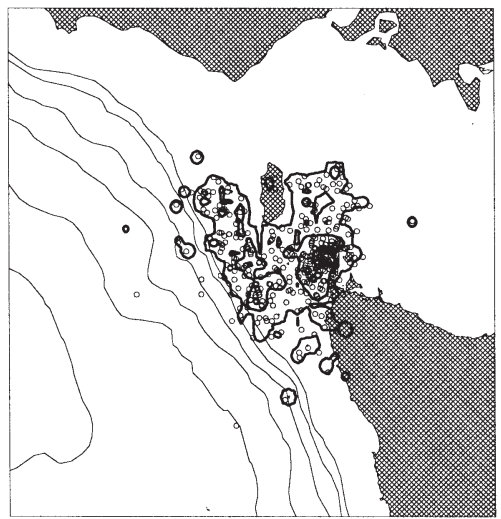

F.

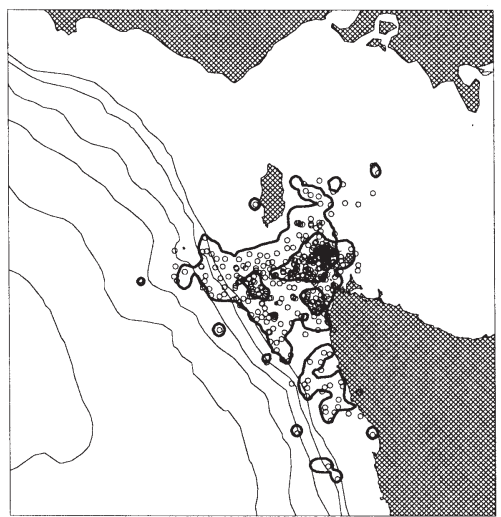

Early Chick-rearing 1996/97

Fig. 2. Distribution of at-sea locations (circles) with 50 and $95 \%$ density contours (heavy solid lines) for shy albatross foraging from Albatross Island during (A-C) incubation and (D-F) chickbrood in each of the 3 years and $(\mathrm{G})$ early-chick rearing in 1996/97. Light solid lines: bathymetric contours

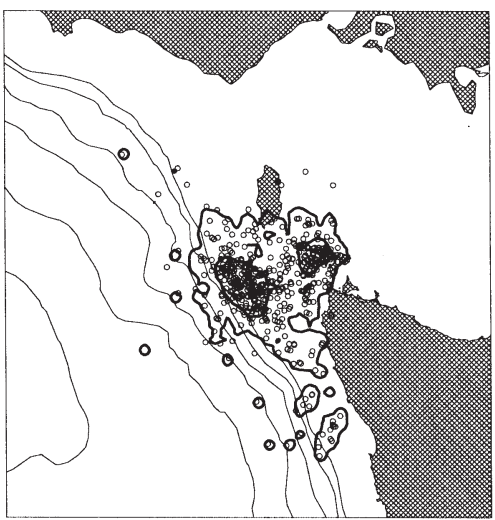




\section{Foraging zone characterization and use}

Between- and within-year comparisons at the population level

During the incubation period, birds foraged either between western Tasmania and southwest Victoria, generally on the western side of King Island, or southwest from the colony towards the edge of the continental shelf. The distribution of locations and the density contours obtained in 1993/94, 1995/96 and 1996/97 are indicated in Fig. 2A-C. The mean overall activity range of the birds (i.e. area encompassing $95 \%$ of locations) computed using home range analyses was $24667 \pm 4827.4 \mathrm{~km}^{2}$, while the mean foraging zone (i.e. area encompassing $50 \%$ of locations) covered $5993 \pm$ $1001.7 \mathrm{~km}^{2}$ (Fig. 2, Table 3). Each year, the highest density of locations (i.e. the activity centre) was positioned from 26 to $79 \mathrm{~km}$ west of Albatross Island (Table 3). Birds were highly consistent in the areas used across years; their activity ranges overlapped by $69 \pm 11.8 \%$, and their foraging zones by $43 \pm 9.0 \%$.

There is both a contraction and a spatial shift in the foraging areas of this population between incubation and brood (Fig. 2D-F). During brood, birds forage both east of King Island and south of Albatross Island, but not north of King Island as they did in incubation. The activity ranges and foraging zones of the population averaged $19067 \pm 1154.7$ and $4167 \pm 945.2 \mathrm{~km}^{2}$ across $3 \mathrm{yr}$, and they were significantly smaller than during the incubation period (paired $t$-tests; $t=2.193, \mathrm{p}=$ 0.079 , and $t=7.57, \mathrm{p}<0.01)$. The activity centre was located $9 \mathrm{~km}$ west of the island in 1993/94, and 10 and $9 \mathrm{~km}$, southwest of the island in 1995/96 and 1996/97 respectively (Table 3 ). Again, the areas used during the brooding period were consistent between years;

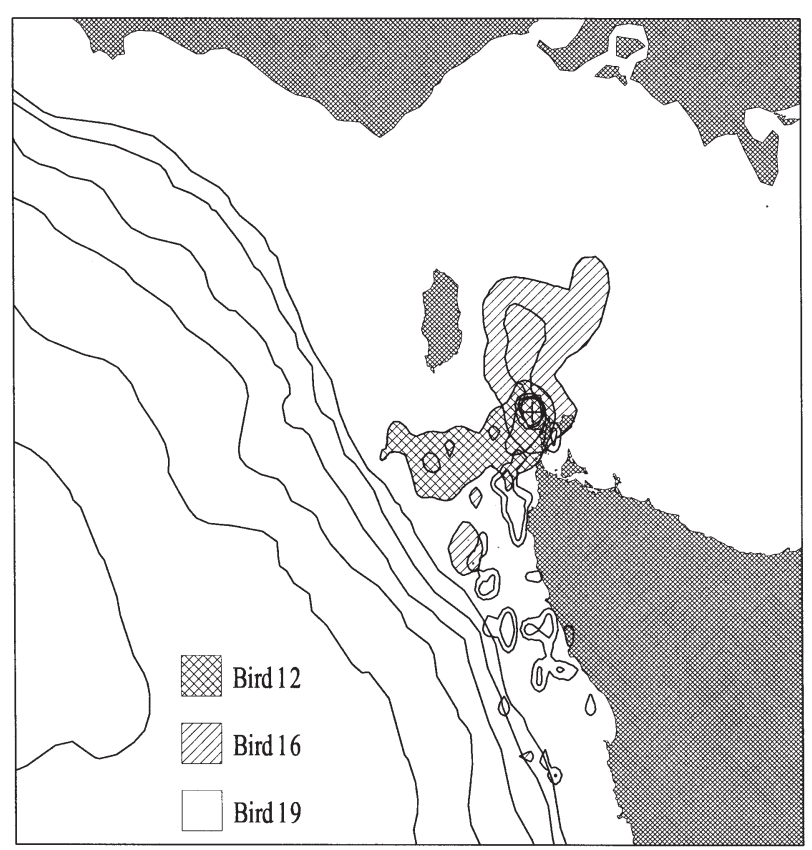

Fig. 3. Fifty and 95\% density contours for Birds 12, 16 and 19 during chick-brood in 1996/97

activity ranges overlapped by $61 \pm 4.2 \%$ and the foraging zones by $44 \pm 14.0 \%$ (Fig. 2, Table 3).

During the chick-rearing stage in January 1997 birds foraged west or southwest from Albatross Island between the colony and the edge of the shelf (Fig. 3). The activity ranges $\left(19400 \mathrm{~km}^{2}\right)$ and the foraging zones $\left(3100 \mathrm{~km}^{2}\right)$ were both similar in size to those observed during the brooding phase that year, but foraging was concentrated further afield. The centre of activity was located $88 \mathrm{~km}$ southwest of the island, close to the birds maximum foraging range (Table 3 ).

Table 3. Thalassarche cauta. Population-level activity ranges and foraging zones estimated from fixed kernel home range analyses. Percentage overlap in area use between 1993/94, 1995/96 and 1996/97 indicated

\begin{tabular}{|c|c|c|c|c|c|c|c|}
\hline \multirow[t]{2}{*}{ Breeding stage } & \multirow[t]{2}{*}{ Year } & \multirow{2}{*}{$\begin{array}{l}\text { No. of } \\
\text { locations }\end{array}$} & \multicolumn{2}{|c|}{ Size $\left(\mathrm{km}^{2}\right)$} & \multirow{2}{*}{$\begin{array}{l}\text { Distance of } \\
\text { activity centre } \\
\text { from colony in } \\
\mathrm{km} \text { (heading) }\end{array}$} & \multicolumn{2}{|c|}{$\begin{array}{l}\% \text { overlap between years } \\
(\text { mean } \pm \mathrm{SD})\end{array}$} \\
\hline & & & $\begin{array}{l}\text { Foraging } \\
\text { zone }\end{array}$ & $\begin{array}{l}\text { Activity } \\
\text { range }\end{array}$ & & $\begin{array}{l}\text { (mean } \\
\text { Foraging zone }\end{array}$ & $\begin{array}{l}\text { SD) } \\
\text { Activity range }\end{array}$ \\
\hline \multirow[t]{4}{*}{ Incubation } & 1993/94 & 209 & 6300 & 27700 & $74(\mathrm{~W})$ & & \\
\hline & $1995 / 96$ & 318 & 6700 & 27200 & $79(\mathrm{~W})$ & $43 \pm 9.0$ & $69 \pm 11.8$ \\
\hline & $1996 / 97$ & 290 & 4800 & 19100 & $26(\mathrm{~W})$ & & \\
\hline & & & $5933 \pm 1001.7$ & $24667 \pm 4827.4$ & & & \\
\hline \multirow[t]{4}{*}{ Chick-brooding } & 1993/94 & 113 & 4900 & 18400 & $9(\mathrm{~W})$ & & \\
\hline & $1995 / 96$ & 394 & 4500 & 20400 & 10 (SW) & $43 \pm 12.5$ & $60 \pm 8.6$ \\
\hline & $1996 / 97$ & 394 & 3100 & 18400 & 9 (SW) & & \\
\hline & & & $4167 \pm 945.2$ & $19067 \pm 1154.7$ & & & \\
\hline $\begin{array}{l}\text { Early chick- } \\
\text { rearing }\end{array}$ & 1996/97 & 497 & 3100 & 19400 & 88 (SW) & - & - \\
\hline
\end{tabular}


Table 4. Thalassarche cauta. Foraging areas of individual birds estimated from fixed kernel home range analyses. Mean sizes of activity range and foraging zone $\pm 1 \mathrm{SD}$ (range) are indicated, as is percent overlap in area use for individuals studied at same time

\begin{tabular}{|c|c|c|c|c|c|c|}
\hline \multirow{2}{*}{ Breeding stage } & \multirow[t]{2}{*}{ Year } & \multirow{2}{*}{$\begin{array}{l}\text { Individuals } \\
\text { (trips ind.- }^{-1} \text { ) }\end{array}$} & \multicolumn{2}{|c|}{ Size $\left(\mathrm{km}^{2}\right)$} & \multicolumn{2}{|c|}{$\%$ overlap between individuals } \\
\hline & & & Foraging zone & Activity range & Foraging zone & Activity range \\
\hline \multirow[t]{3}{*}{ Incubation } & 1993/94 & $\begin{array}{c}6 \\
(1 \text { each) }\end{array}$ & $\begin{array}{c}1900 \pm 1066 \\
(300-3300)\end{array}$ & $\begin{array}{c}7333 \pm 4130 \\
(2900-12200)\end{array}$ & $5 \pm 12.4$ & $17 \pm 16.7$ \\
\hline & 1995/96 & $\begin{array}{c}4 \\
(4 \pm 1.5)\end{array}$ & $\begin{array}{c}3600 \pm 2118 \\
(1800-6000)\end{array}$ & $\begin{array}{c}17125 \pm 11401 \\
(7800-33700)\end{array}$ & $9 \pm 10.3$ & $40 \pm 17.4$ \\
\hline & 1996/97 & $\begin{array}{c}3 \\
\text { (3 each) }\end{array}$ & $\begin{array}{c}3000 \pm 600 \\
(2400-3600) \\
\mathbf{2 6 7 7} \pm \mathbf{1 5 0 6}\end{array}$ & $\begin{array}{l}13233 \pm 5492 \\
(8600-19300) \\
\mathbf{1 1 7 0 8} \pm \mathbf{8 0 3 5}\end{array}$ & $\begin{array}{c}26 \pm 10.8 \\
-\end{array}$ & $\begin{array}{c}46 \pm 15.5 \\
-\end{array}$ \\
\hline \multirow[t]{4}{*}{$\begin{array}{l}\text { Chick- } \\
\text { brooding }\end{array}$} & 1993/94 & $\begin{array}{c}1 \\
(1)\end{array}$ & 600 & 3900 & - & - \\
\hline & 1995/96 & $\begin{array}{c}6 \\
(6 \pm 2.9)\end{array}$ & $\begin{array}{c}2133 \pm 1331 \\
(900-4500)\end{array}$ & $\begin{array}{c}8833 \pm 5965 \\
(3800-19600)\end{array}$ & $33 \pm 23.1$ & $40 \pm 25.7$ \\
\hline & 1996/97 & $\begin{array}{c}10 \\
(4 \pm 0.9)\end{array}$ & $\begin{array}{c}1810 \pm 1165 \\
(500-4200)\end{array}$ & $\begin{array}{c}7170 \pm 3648 \\
(2400-13200)\end{array}$ & $29 \pm 22.3$ & $44 \pm 24.9$ \\
\hline & Average & & $1853 \pm 1202$ & $7565 \pm 4488$ & - & - \\
\hline Early chick-rearing & 1996/97 & $\begin{array}{c}2 \\
(12 \pm 4.9)\end{array}$ & $\begin{array}{l}2900 \pm 1273 \\
(2000-3800)\end{array}$ & $\begin{array}{l}14650 \pm 7000 \\
(9700-19600)\end{array}$ & $65 \pm 28.3$ & $72 \pm 35.9$ \\
\hline
\end{tabular}

Foraging zones of individual birds

In all breeding stages, and at both levels of analysis, individual birds utilized much smaller areas than those used by the population as a whole (Table 4). Activity ranges averaged $11708 \pm 8035,7565 \pm 4488$ and $14650 \pm$ $7000 \mathrm{~km}^{2}$ during the incubation, chick brood and early chick-rearing phases respectively, while during the same periods the foraging zones averaged $2677 \pm 1506$, $1853 \pm 1202$ and $2900 \pm 1273 \mathrm{~km}^{2}$. While smaller areas were used during brood than during either incubation or early chick-rearing, these differences were not statistically significant at either level of analysis $\left(F_{2,29}=1.65\right.$, $\mathrm{p}=0.210 ; F_{2,29}=2.26, \mathrm{p}=0.122$ respectively).

During the incubation and brooding periods there was large variation between individuals in their use of foraging zones, and overlap ranged from 5 to $33 \%$ across years (Table 4). To illustrate, the foraging areas of Birds 12, 16 and 19 in brood 1996/97 are depicted in Fig. 3. Bird 12 foraged west of Albatross Island, between the colony and the edge of the shelf; Bird 16 foraged to the north, off the eastern side of King Island; and Bird 19 headed south and foraged off Tasmania's west coast. The $5 \%$ value in 1993/94 likely resulted from data being collected on only 1 foraging trip for each bird. Activity ranges of individuals overlapped between 40 and $46 \%$ across years (17\% in 1993/94). The 2 birds studied during early chick-rearing in January 1997 foraged in similar areas, and overlap was high: $65 \pm 28.3 \%$ for the foraging zones and $72 \pm$ $35.9 \%$ for the activity ranges.
Foraging zones of both members of a pair. We simultaneously tracked both members of a breeding pair on a number of occasions, but only during brood 1995/96 were there adequate data to make quantitative comparisons. In this instance, the male and female both foraged southwest from Albatross Island, their foraging zones overlapping by $44 \pm 23.1 \% \quad(10 \%$ higher than the average for all individuals studied during this period; Table 4). High overlap within a pair, however, was unusual; for 4 of the other 5 pairs studied, individuals maintained different headings from the island, and subsequently foraged in different areas.

Foraging zones of males and females. The relatively large number of individuals studied during the brooding period (6 in 1995/96 and 10 in 1996/97) allowed for an overall comparison of foraging zone use by males and females. Both the foraging zones $(1767 \pm 1223.7$ and $1950 \pm$ $\left.1177.2 \mathrm{~km}^{2} ; F_{1,15}=0.09, \mathrm{p}=0.765\right)$ and the activity ranges $\left(7289 \pm 5311.6\right.$ and $7875 \pm 3686.2 \mathrm{~km}^{2}{ }_{i} F_{1,15}=0.07, \mathrm{p}=$ 0.798 ) of males and females respectively were similar in size, and also similar in location. The foraging zones of males and females overlapped by $37 \pm 23.6 \%$ in 1995/96 and by $28 \pm 22.3 \%$ in 1996/97, which was similar to the overlap of all individuals studied in these periods (Table 4).

Foraging zones of birds studied multiple times. In this study, 5 birds were tracked by satellite on 2 or more occasions between September 1993 and December 1996. The degree to which their foraging zones overlapped during these periods is indicated in Table 5. Birds 1 and 2 were tracked during incubation and brood in 1995/96, and there was little overlap in foraging zone 
Table 5. Thalassarche cauta. Percentage overlap in foraging zone and activity range for individual albatross tracked for $\geq 2$ sessions between September 1993 and December 1996

\begin{tabular}{|c|c|c|c|}
\hline \multirow[t]{2}{*}{ Individual } & \multirow[t]{2}{*}{ Tracking periods } & \multicolumn{2}{|c|}{$\%$ overlap between years or breeding stages } \\
\hline & & Foraging zone & Activity range \\
\hline \multirow[t]{3}{*}{ Bird 1} & Incubation - 1993/94, 1995/96, 1996/97 & $12 \pm 14.2$ & $40 \pm 25.7$ \\
\hline & Chick-brooding $-1995 / 96$ & 0 & $56 \pm 60.8$ \\
\hline & & (1995/96 only) & (1995/96 only) \\
\hline \multirow{2}{*}{ Bird 2} & Incubation - 1995/96 & $4 \pm 0.4$ & $51 \pm 8.00$ \\
\hline & Chick-brooding - 1995/96 & & \\
\hline Bird 5 & Chick-brooding - 1993/94, 1995/96, 1996/97 & $31 \pm 13.5$ & $29 \pm 10.2$ \\
\hline Bird 6 & Chick-brooding - 1995/96, 1996/97 & $37 \pm 21.9$ & $62 \pm 34.9$ \\
\hline Bird 10 & Incubation - 1993/94, 1996/97 & $20 \pm 4.70$ & $43 \pm 3.20$ \\
\hline
\end{tabular}

Table 6. Thalassarche cauta. Mean size and percentage overlap (areas revisited) by individual birds on successive foraging trips. Data presented at both fine and broad scales

\begin{tabular}{|c|c|c|c|c|c|c|c|c|}
\hline \multirow[t]{3}{*}{ Stage } & \multirow[t]{3}{*}{ Year } & \multirow{3}{*}{$\begin{array}{c}\text { No. of } \\
\text { individuals } \\
\text { (trips) }\end{array}$} & \multicolumn{3}{|c|}{ Fine scale $\left(0.05^{\circ} \times 0.05^{\circ}\right.$ blocks $)$} & \multicolumn{3}{|c|}{ Broad scale $\left(0.25^{\circ} \times 0.25^{\circ}\right.$ blocks $)$} \\
\hline & & & Foraging $\mathrm{z}$ & one size & \% overlap & Foraging zo & one size & $\%$ overlap \\
\hline & & & $\begin{array}{l}\text { Blocks used } \\
(\text { mean } \pm \mathrm{SD})\end{array}$ & $\begin{array}{l}\text { Area } \\
\left(\mathrm{km}^{2}\right)\end{array}$ & $($ mean $\pm \mathrm{SD})$ & $\begin{array}{l}\text { Blocks used } \\
(\text { mean } \pm \mathrm{SD})\end{array}$ & $\begin{array}{l}\text { Area } \\
\left(\mathrm{km}^{2}\right)\end{array}$ & $($ mean $\pm \mathrm{SD})$ \\
\hline \multirow[t]{2}{*}{ Incubation } & 1995/96 & $4(4 \pm 1.5)$ & $49 \pm 29.1$ & 1333 & $14 \pm 6.4$ & $10 \pm 3.4$ & 5639 & $45 \pm 22.4$ \\
\hline & $1996 / 97$ & $3(3 \pm 0)$ & $55 \pm 8.9$ & 1315 & $9 \pm 5.8$ & $11 \pm 1.0$ & 6529 & $32 \pm 9.0$ \\
\hline Chick- & $1995 / 96$ & $6(6 \pm 2.9)$ & $20 \pm 5.5$ & $466 \pm 130.7$ & $10 \pm 4.5$ & $5 \pm 1.0$ & $2770 \pm 612.9$ & $35 \pm 15.6$ \\
\hline brooding & 1996/97 & $10(4 \pm 0.9)$ & $22 \pm 8.5$ & $528 \pm 203.5$ & $13 \pm 6.2$ & $5 \pm 1.1$ & $2968 \pm 625.7$ & $43 \pm 15.8$ \\
\hline Chick-rearing & 1996/97 & $2(12 \pm 4.9)$ & $36 \pm 2.8$ & $861 \pm 67.9$ & $13 \pm 1.4$ & $7 \pm 0$ & $4155 \pm 0$ & $37 \pm 2.8$ \\
\hline
\end{tabular}

use between stages. The remaining individuals were studied during the same breeding stage in $\geq 2 \mathrm{yr}$ and at this scale the birds' degree of site fidelity was variable. For example, during incubation in both 1995/96 and 1996/97 Bird 1 foraged northwest of King Island, whereas in 1993/94 he foraged to the south, off Tasmania's west coast. While individuals seemed to concentrate their foraging efforts over particular ocean patches (see next section), fidelity to these patches did not necessarily hold across years.

Do birds forage in similar locations on successive trips to sea?

During the incubation period, birds did not return to the same geographical location to feed from one trip to the next (see fine scale results in Table 6), but their foraging was not random. Birds maintained a constant heading from the Island on most successive foraging trips, and this level of consistency was demonstrated by increased overlap scores at the broad scale; $45 \pm 22.4 \%$ across individuals in 1995/96 and $32 \pm 9.0 \%$ in 1996/97.
During brood, birds again maintained a constant heading from Albatross Island, searching the same broad patches of ocean on almost all successive foraging trips. To illustrate, 2 trips of Bird 8 (1995/96), who foraged exclusively east of King Island, and Bird 17 (1996/97), who foraged exclusively west of Albatross Island, are indicated in Fig. 4. Broad scales overlap on successive trips averaged $35 \pm 15.6 \%$ across individuals in 1995/96 and $43 \pm 15.8 \%$ in 1996/97 (Table 6).

Site fidelity during early chick-rearing was similar; averaging $13 \pm 1.2$ and $37 \pm 2.8 \%$ across successive foraging trips at the fine and broad scales, respectively (Table 6).

\section{Fine-scale behaviour}

Instantaneous and average daily rates of travel

Instantaneous rates of travel between locations separated by $\leq 2 \mathrm{~h}$ were similar between years (1995/96, $16 \pm 14.5 \mathrm{~km} \mathrm{~h}^{-1}, \mathrm{n}=452 ; 1996 / 97,14 \pm 14.2 \mathrm{~km} \mathrm{~h}^{-1}, \mathrm{n}=$ $785 ; F_{1,22}=0.28, \mathrm{p}>0.05$ ), and similar during all breed- 


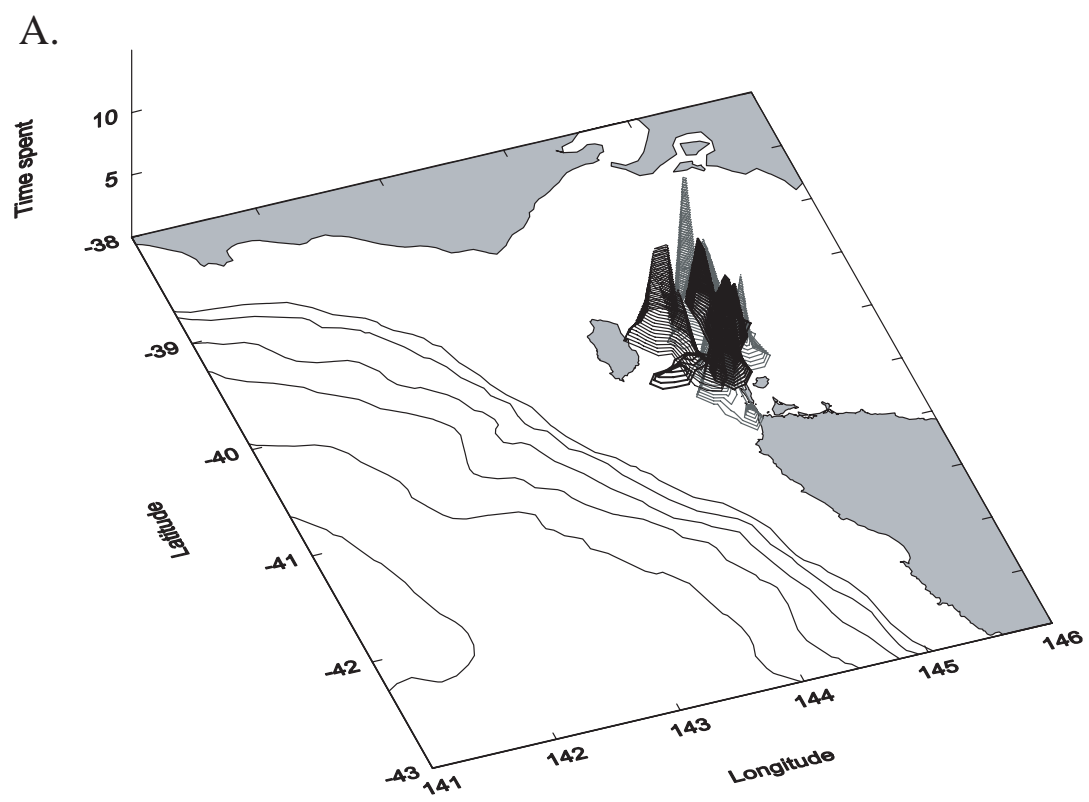

B.

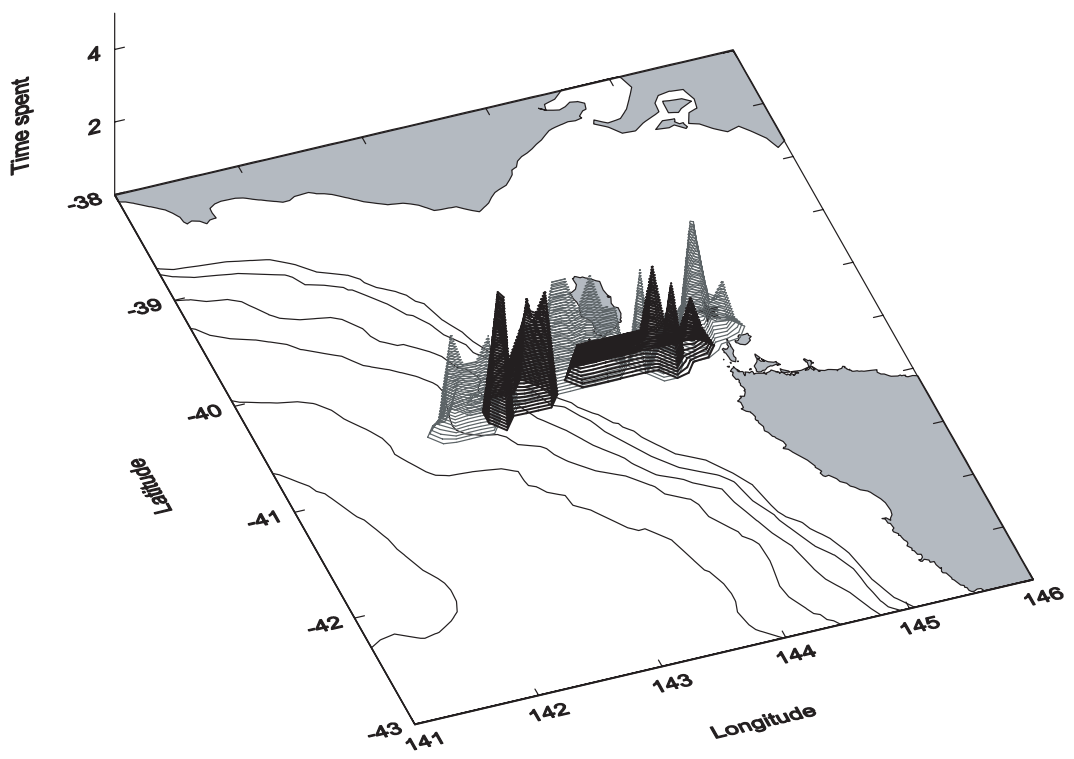

Fig. 4. Successive foraging trips during chick-brood for (A) Bird 8 in 1995/96 and (B) Bird 17 in 1996/97

ing stages, but they differed according to time of day, with birds traveling faster during the day than at night (Table 7). Average rates of travel were similar between years during both the day $\left(1995 / 96,12 \pm 5.1 \mathrm{~km} \mathrm{~h}^{-1}, \mathrm{n}=\right.$ $49 \mathrm{~d}_{i}$ 1996/97, $11 \pm 3.8 \mathrm{~km} \mathrm{~h}^{-1}, \mathrm{n}=107 \mathrm{~d}_{i} F_{1,21}=0.002$, $\mathrm{p}>0.05)$ and the night $\left(1995 / 96,9 \pm 7.1 \mathrm{~km} \mathrm{~h}^{-1}, \mathrm{n}=\right.$ $49 \mathrm{~d}_{i}$ 1996/97, $8 \pm 5.6 \mathrm{~km} \mathrm{~h}^{-1}, \mathrm{n}=107 \mathrm{~d}_{i} F_{1,21}=0.018$, $\mathrm{p}>0.05$ ), and also similar across stages of the breeding season (Table 7). Rates of travel were, however, greater during the day than at night (Table 7). Moonphase influenced the rate of travel at night $\left(F_{2,49}=3.71\right.$, $\mathrm{p}<0.05)$, with traveling speeds significantly higher during full moon (full moon, $10 \pm 6.2 \mathrm{~km}$ $\mathrm{h}^{-1}, \mathrm{n}=49$; quarter and 3-quarter phases, $8 \pm 6.4 \mathrm{~km} \mathrm{~h}^{-1}, \mathrm{n}=90$; new moon, $7 \pm 5.3 \mathrm{~km} \mathrm{~h}^{-1}, \mathrm{n}=37$, Tukey's HSD $\mathrm{p}<0.05$ for all).

Despite some nighttime activity, shy albatross traveled mainly during the day. During incubation $74 \pm 12.9 \%$ ( $\mathrm{n}=$ $24 \mathrm{~d}$ ) of the distance traveled each day was covered during daylight and this proportion increased to $82 \pm 10.5 \%(\mathrm{n}=$ $22 \mathrm{~d})$ and $82 \pm 14.9 \%(\mathrm{n}=29 \mathrm{~d})$ during chick-brood and early chick-rearing, respectively $\left(F_{2,16}=3.63, \mathrm{p}=0.050\right)$, as the number of daylight hours per day increased $\left(R_{\mathrm{s}}=+0.256, \mathrm{p}=0.026, \mathrm{n}=\right.$ 75).

\section{Activity patterns at sea}

Proportion of time wet and dry. During incubation birds spent an average of $69 \%$ of the daytime flying and $31 \%$ of daytime sitting on the sea (Table 8), while during the night the majority of time $(80 \%)$ was spent on the water. Birds spent significantly more of the night than the day sitting on the water during this stage of the breeding season $\left(F_{1,8}=74.2, \mathrm{p}<0.001\right)$. Across complete foraging trips, time was equally allocated between flying and sitting on the sea; however, individual variation was substantial (Table 8).

Chick-brooding birds spent $73 \%$ of the day in flight, a proportion similar to that during incubation $\left(F_{1,7}=0.15, \mathrm{p}>\right.$ $0.05)$, but in the chick-brooding stage they flew for significantly more of the night $\left(54 \% ; F_{1,7}=10.54, \mathrm{p}<0.05\right)$ and for more of their total time at sea $(68 \%$; $\left.F_{1,7}=23.95, \mathrm{p}<0.01\right)$. Birds flew for equal proportions of the day and night during this stage $\left(F_{1,10}=4.21, \mathrm{p}=0.067\right)$. The apparent stage differences are, however, an artifact of relationships with moon phase. Birds flew for significantly more of the night when the moon was full $\left(F_{2,31}=3.89, \mathrm{p}<0.05\right.$; full moon, $62 \pm 33.9 \%, \mathrm{n}=6 \mathrm{~d}$; quarter and 3-quarter moon, $26 \pm 29.5 \%, \mathrm{n}=21 \mathrm{~d}$; new moon, $23 \pm 21.9 \%$; Tukey's HSD p < 0.05), and there was a full moon only during the brooding period. With these data excluded there is no stage difference in the proportion of the night spent flying $\left(F_{1,4}=2.43, \mathrm{p}>0.05\right.$; incubation, $21 \pm$ $26.7 \%, \mathrm{n}=23$; chick-brooding, $44 \pm 25.0 \%, \mathrm{n}=5$ ). Dur- 
ing incubation, wind speed did not influence the proportion of time birds spent flying (day, $\mathrm{R}_{\mathrm{s}}=0.182, \mathrm{p}>$ $0.05, \mathrm{n}=67$; night, $\mathrm{R}_{\mathrm{s}}=0.184, \mathrm{p}>0.05, \mathrm{n}=38$ ). While this was also the case during brood in the day $\left(\mathrm{R}_{\mathrm{s}}=\right.$ $0.190, \mathrm{p}>0.05, \mathrm{n}=56$ ), there was a significant negative relationship between wind speed and the proportion of time spent flying at night $\left(\mathrm{R}_{\mathrm{s}}=-0.698, \mathrm{p}<0.05, \mathrm{n}=9\right)$. The latter relationship again appears to result from relationships with moon phase. Birds flew at night during full moon irrespective of wind speed, but they

Table 7. Thalassarche cauta. Instantaneous and daily rates of travel (mean $\pm \mathrm{SD}$ ). Sample sizes in parentheses

\begin{tabular}{|c|c|c|c|c|c|}
\hline & & \multirow[t]{2}{*}{ Incubation } & \multirow[t]{2}{*}{ Chick-brooding } & \multirow{2}{*}{$\begin{array}{l}\text { Early chick- } \\
\text { rearing }\end{array}$} & Statistics \\
\hline & & & & & Stage $\quad$ Time of day \\
\hline $\begin{array}{l}\text { Instantaneous rate } \\
\text { of travel }\left(\mathrm{km} \mathrm{h}^{-1}\right)\end{array}$ & $\begin{array}{l}\text { Overall } \\
\text { Day (pooled) } \\
\text { Night (pooled) }\end{array}$ & $17 \pm 19.8$ & $\begin{array}{l}15 \pm 11.7(515) \\
16 \pm 15.6(910) \\
12 \pm 9.6(327)\end{array}$ & $13 \pm 10.2(356)$ & $\begin{aligned} & F_{2,23}=0.1, \mathrm{p}> 0.05 \\
& F_{1,39}=6.9, \mathrm{p}<0.05\end{aligned}$ \\
\hline \multirow[t]{2}{*}{$\begin{array}{l}\text { Mean daily rate } \\
\text { of travel }\left(\mathrm{km} \mathrm{h}^{-1}\right)\end{array}$} & $\begin{array}{l}\text { Day } \\
\text { Overall }\end{array}$ & $12 \pm 5.1(46)$ & $\begin{array}{l}11 \pm 3.8(61) \\
11 \pm 4.2(156)\end{array}$ & $10 \pm 3.9(49)$ & $F_{2,153}=1.08, \mathrm{p}>0.05$ \\
\hline & $\begin{array}{l}\text { Night } \\
\text { Overall }\end{array}$ & $9 \pm 6.2(46)$ & $\begin{array}{l}8 \pm 6.6(61) \\
8 \pm 6.2(156)\end{array}$ & $7 \pm 5.8(49)$ & $\begin{aligned} F_{2,153}=0.71, \mathrm{p}> & 0.05 \\
Z & =-5.28, \mathrm{p}<0.001\end{aligned}$ \\
\hline
\end{tabular}

Table 8. Thalassarche cauta. Activity patterns of individual birds during the 1996/97 season relative to breeding stage and time of day

\begin{tabular}{|c|c|c|c|c|c|c|c|c|}
\hline \multirow{2}{*}{$\begin{array}{l}\text { Breeding stage } \\
\text { Individual }\end{array}$} & \multirow{2}{*}{$\begin{array}{l}\text { Trip } \\
\text { no }\end{array}$} & \multirow{2}{*}{$\begin{array}{l}\text { Start } \\
\text { date }\end{array}$} & \multirow{2}{*}{$\begin{array}{c}\text { Trip } \\
\text { duration } \\
\text { (h) }\end{array}$} & \multicolumn{2}{|c|}{ Daytime } & \multicolumn{2}{|c|}{ Nighttime } & \multirow{2}{*}{$\begin{array}{l}\% \text { total } \\
\text { time at sea } \\
\text { spent on } \\
\text { water }\end{array}$} \\
\hline & & & & $\begin{array}{l}\% \text { total } \\
\text { time } \\
\text { deployed }\end{array}$ & $\begin{array}{l}\text { \% daytime } \\
\text { spent on } \\
\text { water }\end{array}$ & $\begin{array}{l}\text { \% total } \\
\text { time } \\
\text { deployed }\end{array}$ & $\begin{array}{l}\% \text { nighttime } \\
\text { spent on } \\
\text { water }\end{array}$ & \\
\hline \multicolumn{9}{|l|}{ Incubation } \\
\hline \multirow{3}{*}{ Bird 22} & 1 & 03 Oct & 70.8 & 60.4 & 47.1 & 39.6 & 68.3 & 55.5 \\
\hline & 2 & 09 Oct & 68.9 & 60.3 & 40.2 & 39.7 & 67.0 & 50.7 \\
\hline & 3 & 14 Oct & 48.2 & 63.2 & 31.9 & 36.8 & 73.5 & 47.3 \\
\hline \multirow[t]{3}{*}{ Bird 23} & 1 & 03 Oct & 43.7 & 57.3 & 10.1 & 42.7 & 69.9 & 35.6 \\
\hline & 2 & 08 Oct & 30.5 & 66.6 & 28.8 & 33.4 & 99.3 & 49.1 \\
\hline & 3 & 10 Oct & 27.0 & 66.4 & 30.5 & 33.5 & 72.6 & 44.6 \\
\hline \multirow[t]{2}{*}{ Bird 24} & 1 & 04 Oct & 127.4 & 63.7 & 40.1 & 36.2 & 97.5 & 60.8 \\
\hline & 2 & 14 Oct & 99.6 & 64.5 & 21.4 & 35.5 & 77.7 & 41.3 \\
\hline Bird $25^{\mathrm{a}}$ & 1 & 04 Oct & 32.4 & 48.3 & 27.0 & 51.7 & 92.0 & 60.7 \\
\hline \multicolumn{2}{|c|}{ Incubation mean } & & & & $30.8 \pm 11.05$ & & $79.8 \pm 12.17$ & $49.5 \pm 8.51$ \\
\hline \multicolumn{9}{|c|}{ Chick-brooding } \\
\hline \multirow[t]{3}{*}{ Bird 24} & 1 & $16 \mathrm{Dec}$ & 16.0 & 59.7 & 3.6 & 40.3 & 85.4 & 36.3 \\
\hline & 2 & $17 \mathrm{Dec}$ & 21.5 & 69.9 & 9.7 & 30.1 & 59.7 & 24.5 \\
\hline & 3 & $19 \mathrm{Dec}$ & 14.8 & 100 & 13.1 & 0.0 & - & 13.1 \\
\hline \multirow[t]{6}{*}{ Bird 26} & 1 & $20 \mathrm{Dec}$ & 26.8 & 72.4 & 13.8 & 23.7 & 92.7 & 32.0 \\
\hline & 2 & $23 \mathrm{Dec}$ & 17.5 & 100 & 61.8 & 0.0 & - & 61.8 \\
\hline & 3 & $25 \mathrm{Dec}$ & 17.7 & 100 & 44.4 & 0.0 & - & 44.4 \\
\hline & 4 & $26 \mathrm{Dec}$ & 17.8 & 100 & 29.6 & 0.0 & - & 29.6 \\
\hline & 5 & $27 \mathrm{Dec}$ & 26.5 & 76.4 & 35.5 & 23.6 & 27.3 & 33.5 \\
\hline & 6 & $29 \mathrm{Dec}$ & 29.8 & 78.8 & 9.8 & 21.2 & 33.3 & 14.7 \\
\hline \multirow[t]{3}{*}{ Bird 27} & 1 & $17 \mathrm{Dec}$ & 20.2 & 66.4 & 28.4 & 33.6 & 72.9 & 42.2 \\
\hline & 2 & $19 \mathrm{Dec}$ & 10.3 & 100 & 34.4 & 0.0 & - & 34.4 \\
\hline & 3 & $20 \mathrm{Dec}$ & 28.3 & 77.4 & 11.5 & 22.6 & 27.1 & 15.0 \\
\hline \multirow[t]{3}{*}{ Bird 28} & 1 & $22 \mathrm{Dec}$ & 21.1 & 69.8 & 13.3 & 30.2 & 56.4 & 26.2 \\
\hline & 2 & $23 \mathrm{Dec}$ & 20.8 & 69.4 & 35.3 & 30.6 & 4.7 & 25.9 \\
\hline & 3 & $24 \mathrm{Dec}$ & 18.4 & 65.8 & 41.8 & 34.2 & 44.8 & 42.8 \\
\hline Bird 29 & 1 & $27 \mathrm{Dec}$ & 36.9 & 83.1 & 40.1 & 16.9 & 5.3 & 34.2 \\
\hline \multicolumn{4}{|c|}{ Chick-brooding mean } & & $26.6 \pm 16.41$ & & $46.3 \pm 29.97$ & $31.9 \pm 12.18$ \\
\hline
\end{tabular}



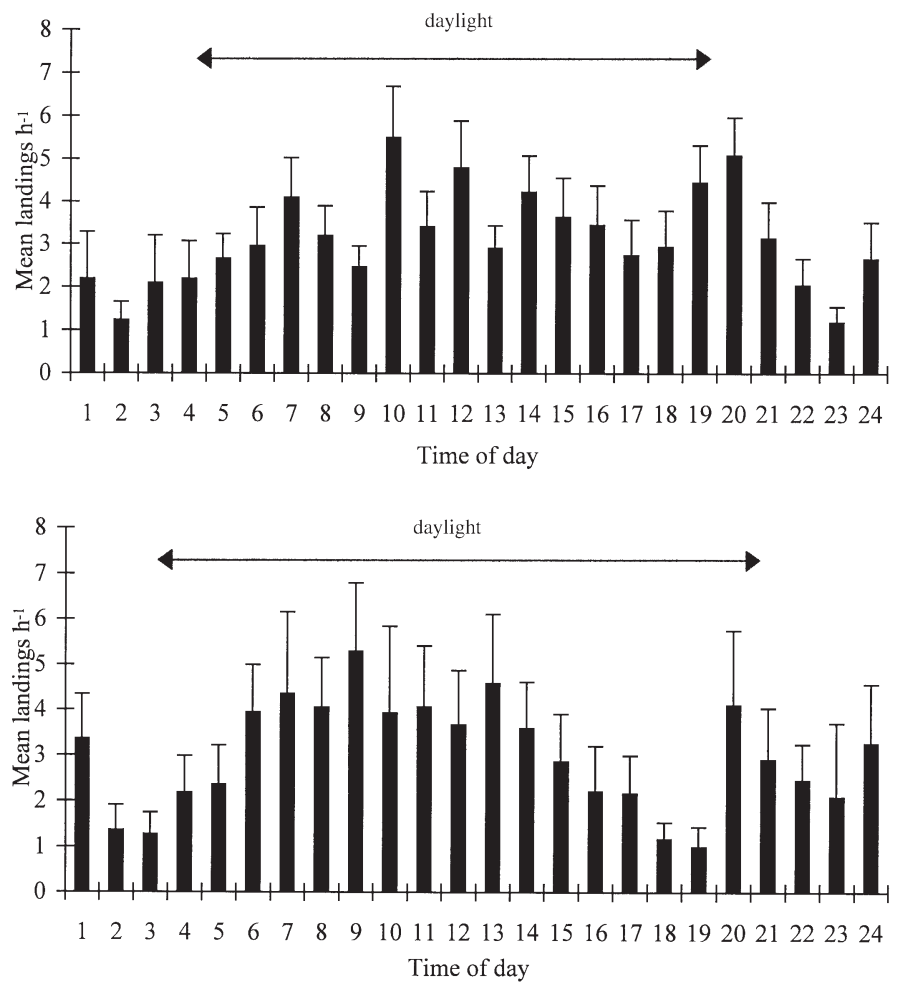

Fig. 5. Mean number of landings on water for each hour of day during (A) incubation and (B) chick-brooding, 1996/97. Double-headed arrows indicate daylight period

did not fly on other nights even when winds were strong. The negative relationship eventuated as wind speed was weaker during full moon $(6.1 \pm 4.6$ vs $9.9 \pm$ $4.3 \mathrm{~m} \mathrm{~s}^{-1}$ ).

A.

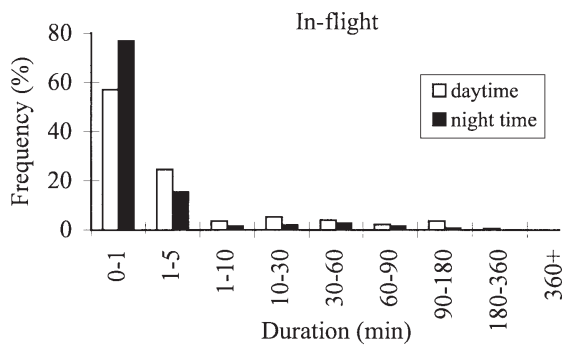

C.

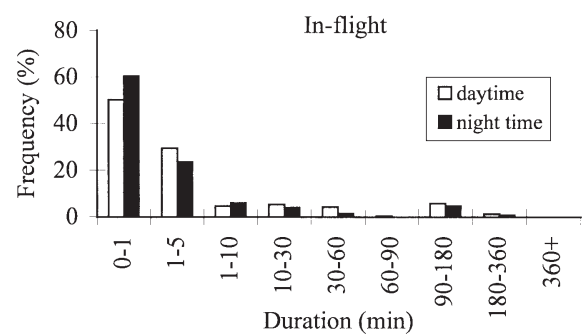

Water landings. Birds averaged from 1 to 6 landings on the water $\mathrm{h}^{-1}$ (range 0 to 24; Fig. 5). The relative degree of activity was not constant across the day during either incubation or brood $\left(\chi_{23}^{2}=186.1, \mathrm{p}<0.01 ; \chi^{2}{ }_{23}=282.2, \mathrm{p}<0.01\right.$ respectively), with most landings occurring near midday and dusk. The distribution of landings was similar between stages of the breeding season $\left(\chi^{2}{ }_{47}=\right.$ $6.4, p>0.90$; Fig. 5), and the landing frequency at night was unrelated to moon phase (full moon, $1.1 \pm 1.11$; quarter and 3-quarter phases, $0.7 \pm$ 0.61 ; new moon, $1.5 \pm 1.11 ; F_{2,30}=2.51, \mathrm{p}>0.05$ ).

During incubation, birds landed more frequently during the day when wind speeds were low $\left(\mathrm{R}_{\mathrm{s}}=-0.254, \mathrm{p}<0.05, \mathrm{n}=67\right)$, while during chick brood the opposite trend was observed $\left(\mathrm{R}_{\mathrm{s}}=0.282, \mathrm{p}<0.05, \mathrm{n}=56\right)$. Both relationships were weak and wind speed accounted for less than $6 \%$ of the variation in landing frequency. Wind speed was unrelated to landing frequency at night $\left(\mathrm{R}_{\mathrm{s}}=-0.107, \mathrm{p}>0.05, \mathrm{n}=38, \mathrm{R}_{\mathrm{s}}=0.204\right.$, $\mathrm{p}>0.05, \mathrm{n}=9$, for incubation and brood respectively).

Distribution of wet/dry bout durations. The distribution of both wet and dry bouts was dominated by intervals lasting $<5$ min (Fig. 6), but these distributions differed with respect to time of day and breeding stage. During incubation, longer flying bouts predominated during the day $\left(\chi_{15}^{2}=56.7, p<0.001\right.$; Fig. $\left.6 \mathrm{~A}\right)$, while longer wet bouts predominated at night $\left(\chi^{2}{ }_{15}=56.8, \mathrm{p}<0.001\right.$; Fig. 6B). During brood, the distribution of the duration of flying bouts was similar during the day and night $\left(\chi^{2}{ }_{15}=8.5, p=0.903 ;\right.$ Fig. $\left.6 \mathrm{C}\right)$, but longer wet periods

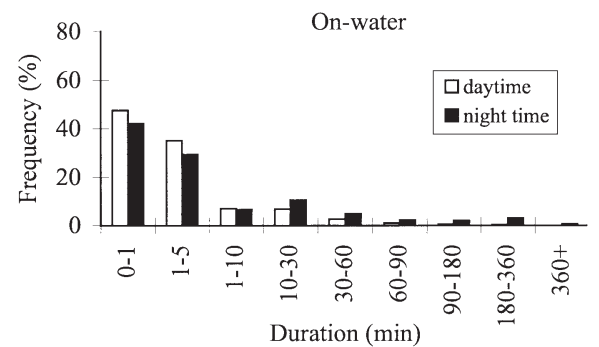

D.

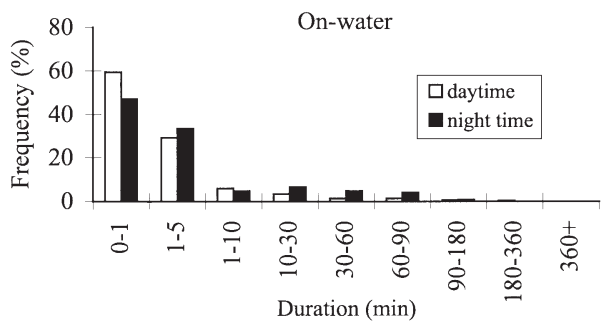

Fig. 6. Frequency distributions for duration of in-flight and on-water bouts during day and night for $(\mathrm{A}, \mathrm{B})$ incubation and (C,D) chick-brooding periods, 1996/97 
again predominated at night $\left(\chi^{2}{ }_{7}=24.9, \mathrm{p}=0.052\right.$; Fig. 6D). Brooding birds flew for longer periods during the day and night $\left(\chi^{2}{ }_{15}=31.7, \mathrm{p}<0.01 ; \chi^{2}{ }_{15}=34.9, \mathrm{p}<\right.$ 0.01), while incubating birds sat on the water for longer periods during the day $\left(\chi^{2}{ }_{17}=46.7, \mathrm{p}<0.001\right)$. There were no stage differences in the distribution of wet bouts at night $\left(\chi^{2}{ }_{17}=11.8, \mathrm{p}=0.810\right)$.

\section{SST within the foraging zones}

Between incubation and early chick-rearing, birds from Albatross Island foraged in waters that ranged from 12 to $17^{\circ} \mathrm{C}$. SSTs within the birds foraging zones were similar between years.

\section{DISCUSSION}

This study reports on the at-sea distribution of shy albatross breeding at Albatross Island, Tasmania. Unique amongst albatrosses studied to date, shy albatross are relatively sedentary both during and outside the breeding season (Brothers et al. 1997, 1998). Birds spend short periods at sea while breeding (generally $<3$ d) and forage close to the colony over continental shelf and slope waters that range from 12 to $17^{\circ} \mathrm{C}$. The maximum foraging range of breeding birds averages $<200 \mathrm{~km}$. At the population level, the foraging zones are highly consistent between years. On successive foraging trips, individual birds tend to maintain a constant heading from the breeding colony, and they repeatedly search the same broad patches of water in search of food.

\section{Effect of carrying satellite packs}

Foraging trips of birds carrying satellite packs (1.9 to $3.4 \%$ of body mass) were extended in duration throughout the breeding season relative to birds carrying VHF transmitters ( 0.4 to $0.5 \%$ body mass). Similar to previous attempts to study the foraging locations of shy albatross post-brood (see Brothers et al. 1998) our efforts during this study also resulted in nest desertions. We were, however, successful in 1997/98 during a later study with deployments at Mewstone. Smaller packs ( 0.8 to $1.1 \%$ adult body mass) were attached to birds early in the brooding period, and they remained in place until late chick-rearing. Both birds continued to breed. We suggest that the success of the latter study resulted from earlier device attachment, as this species seems less affected by handling stresses early in the breeding season (i.e. until late in the chick-brooding phase). However, the confounding effects of the use of smaller transmitters at Mewstone makes it difficult to resolve whether the positive outcome was purely a result of reduced handling stress or reduced handling stress combined with lower energetic costs.

While the disturbance and the energetic costs of carrying devices have received little attention for albatrosses, both this study and that of Waugh et al. (1999) have shown that foraging trips of satellite-bearing birds are likely to be extended. Nest desertions have also occurred with other species including light-mantled sooty albatross Phoebetria palpebrata at Macquarie Island (Weimerskirch \& Robertson 1994) and wandering Diomedia spp. and royal albatrosses Diomedea sanfordi in New Zealand (D. G. Nicholls pers. comm.). If tracking studies are to progress it is critical that field methods be precisely reported, including breeding status and activity of the birds, the size and attachment methods of the instruments, the breeding outcomes, and sighting reports of failed/deserting individuals in subsequent years. Dissemination of this sort of information for albatrosses, as has occurred for penguins (Wilson et al. 1997), will aid appropriate study design and help to minimize impacts upon the birds.

\section{Foraging zones, foraging strategy and foraging site fidelity}

At the population level, shy albatross from Albatross Island are highly consistent in their foraging zone use between years. Coupled with this, their traveling speeds, trip durations and maximum foraging ranges were also similar between years. Such inter-annual consistency suggests relatively constant prey availability that may, in turn, relate to the consistent oceanographic conditions, particularly SST, observed within their foraging zones.

While there were fine-scale changes in foraging locations, individual birds maintained fidelity to broad patches of ocean on successive trips to sea. These patches differed between individuals, indicating that while prey was most likely widely available, its distribution was patchy. Higher site fidelity at a broader scale presumably indicates that the probability of encountering prey is high given a certain amount of foraging effort in a particular area (see Hunt et al. 1998). In future studies, however, it would be useful to have a measure of foraging success (e.g. mass change or estimates of the quantity of food consumed) to correspond with the degree of site fidelity.

\section{Comparison with other species}

Few studies have quantitatively examined foraging site fidelity either for individuals or for populations of 
seabirds (but see Hunt et al. 1998). Comparing the current data with those that do exist is difficult because of both methodological differences (some studies are quantitative while others are not) and also differences in the scale of the areas considered. Nevertheless, black-browed albatross Thalassarche melanophris from Kerguelen Island (Weimerskirch et al. 1997b, Weimerskirch 1998), wandering albatross from the Crozet Islands (Weimerskirch et al. 1993, Weimerskirch 1998), and black-footed albatross Phoebastria nigripes from the Hawaiian Islands (Anderson et al. 2000) have been reported to show some degree of foraging site fidelity.

While raising chicks, black-browed albatross from Kerguelen Island consistently forage over shelf breaks either along the eastern side of Kerguelen Island, or to the north of Heard Island. Like a number of other seabird species (Bost et al. 1997, Hull et al. 1997, Waugh et al. 1999), they are thought to exploit resources located within the Antarctic PFZ (Weimerskirch et al. 1997b). Presumably the proximity of the PFZ to Kerguelen Island provides abundant and predictable resources, possibly accounting for the consistent foraging locations of black-browed albatross between years (Weimerskirch et al. 1997b, Weimerskirch 1998). Also, while rearing chicks both wandering albatross from the Crozet Islands and black-footed albatross from Tern Island show site fidelity to particular shelf break areas. Wandering albatross use areas close to the colony, while black-footed albatross commute to North America to forage over the continental shelf off the coast of Oregon.

Black-legged kittiwakes Rissa tridactyla also return to the same foraging areas on the majority of trips to sea (Irons 1998), and this is similar to the findings of Becker et al. (1993) for common terns Sterna hirundo. Inter-annual differences in foraging zone use for shags Phalacrocorax aristotelis (Wanless et al. 1991) were presumed to relate to changes in the distribution of sandeels Ammodytes spp., their predominant prey. When prey can be located with some degree of spatial or temporal predictability, individuals from a number of seabird species seem to cue in to and repeatedly use areas where they have had previous success, at least in the short term.

\section{Rates of travel and patterns of activity at sea}

At Albatross Island, rates of travel were similar both across years and across stages of the breeding season. Detailed activity data also indicated, after accounting for the effect of moon phase, that birds flew for similar proportions of the day and night during incubation and brood. There were, however, clear diurnal differences with birds covering greater distances and traveling for a greater proportion of the day than the night.

Birds responded to increasing day-length in summer by increasing the relative distance traveled during the day. Between incubation and chick-rearing, birds also decrease their foraging range without increasing their rate of travel, indicating either that they switch prey species between stages, or that changes in resource distribution or abundance result in prey becoming relatively more available as chicks hatch. The highenergy demands of early chick-rearing may be at least be partially offset by coinciding with spring/summer blooms in productivity (Harris et al. 1987), and longer summer days, as was found for wandering albatross at the Crozet Islands (Salamolard \& Weimerskirch 1993).

Birds were increasingly active after sunrise, their landing frequency was high and relatively constant between 07:00 and 13:00 $\mathrm{h}$, with a secondary peak in late evening (19:00 to 22:00 h). During brood, landings were uncommon between 02:00 and 04:00 $\mathrm{h}$, when birds sat on the water, and again between 18:00 and 20:00 h, when they tended to be flying. These overall patterns are similar to diurnal patterns observed in the species diving behaviour (Hedd et al. 1997, unpubl. data), as most diving occurs between early morning and midday with a second peak near dusk.

While raising chicks, shy albatross feed predominantly on surface schooling jack mackerel Trachurus declivis and redbait Emmelichthys nitidus (Hedd \& Gales 2001), 2 species that occur abundantly in the coastal waters off southern Australia (Williams \& Pullen 1993). Mackerel schools form over the shelf during summer and autumn to feed on surface swarms of Australian krill Nyctiphanes australis. Schools come close to the surface just after sunrise, disperse to depth throughout the day in bright sunshine, and form again in the last few hours of daylight (Williams \& Pullen 1993). Shy albatross, then, are largely predatory, feeding on live surface-schooling prey during the day.

Birds are also active at night but their degree of nocturnal activity is strongly influenced by moonphase. They fly for a greater proportion of the night and they cover greater distances during full moon. There was, however, no relationship between moon phase and the birds' landing frequency. If landings coincide with attempted prey captures, then the fact that their frequency is unrelated to moon phase could indicate that moonlight is used for traveling, but not for foraging, as has been suggested for wandering albatross (Weimerskirch et al. 1997c).

Wind speed did not effect the proportion of time that shy albatross spent flying during the day, corroborating earlier findings that they do not make extensive use of winds while foraging (Brothers et al. 1998). While other albatross species use winds when com- 
muting to and from distant foraging grounds, wandering albatross also did not use winds extensively when foraging in the neritic environment (Weimerskirch et al. 1993). Energetic studies indicate that expenditure of foraging albatrosses is high when they slow down and frequently change direction, when they land and take off frequently, and when they fly without the use of the wind (Bevan et al. 1995, Weimerskirch et al. 2000). The fact that shy albatross do not make extensive use of winds indicates that they could incur substantial flight costs; however, such costs are likely largely offset by their short foraging ranges.

The overall traveling speeds of shy albatross are considerably slower than those reported for other albatross species (Weimerskirch et al. 1993, 1994, Weimerskirch \& Robertson 1994). While this likely relates to the fact that their flight is not strongly wind assisted, slower traveling speeds may also directly relate to their foraging strategy. Shy albatross repeatedly search specific areas, and they likely forage continually while at sea, at least during the day. If this is the case, low flight speeds are well adapted to their continual search for prey.

\section{Conclusions}

Satellite tracking has been vital to advancing our understanding of habitat use by marine birds, particularly albatrosses. Conducting investigations of habitat use both across the breeding season and across years and combining such studies with long-term investigations of diet and behaviour are central to understanding both foraging ecology and the environmental factors that influence it. For a number of albatross species, there is a critical need to identify both foraging ranges and distribution of birds, including by age, sex and season, such that areas of interaction with longline fisheries can be identified, and the resulting bycatch mitigated (Cooper et al. 2001).

Acknowledgements. We are very grateful to Graham Robertson, who provided us with the satellite transmitters that initially enabled work to get underway. Thanks to C. Sidot, and V. and J. Klinger at CNRS in France for access to custom software that quantified the birds use of the marine environment, and to Jean-Yves Georges for his help running the program. We thank Tim Reid at TASPAWS for writing the velocity filtering program, Lee Hedd for his help producing the figures, Catherine Bone, Lee Hedd, Megan Jones, Di Moyle, David Pemberton, Tim Reid, and Jenny Scott for help in the field, and Neil Smith for transport to the Islands. We also thank the CSIRO for providing us with SST data, and especially Kim Badcock for his help extracting it. This work was funded by Environment Australia, the Australian Fisheries Management Authority, the Australian Research Council, Tasmanian Parks and Wildlife Service, the Royal Zoological Society of New South Wales and the University of Tasmania.

\section{LITERATURE CITED}

Anderson DJ, Fernandez P, Cousins KL, Sievert PR (2000) Foraging destinations of breeding laysan and black-footed albatross in relation to longline fishery activity. 2nd Int Conf on the Biology and Conservation of Albatross and other Petrels, Honolulu. US Fish Wildl Serv, Honolulu, HI (abstract)

Becker PH, Frank D, Sudmann SR (1993) Temporal and spatial pattern of common tern Sterna hirundo foraging in the Wadden Sea. Oecologia 93:389-393

Bevan RM, Butler PJ, Woakes AJ, Prince PA (1995) The energy expenditure of free-ranging black-browed albatross. Phil Trans R Soc Lond B 350:119-131

Bost CA, Georges JY, Guinet C, Cherel Y and 6 others (1997) Foraging habitat and food intake of satellite-tracked king penguins during the austral summer at Crozet Archipelago. Mar Ecol Prog Ser 150:21-33

Brothers NP, Reid T, Gales R (1997) Shy albatross Diomedea cauta cauta at-sea distribution derived from records of band recoveries and colour marked birds. Emu 97: 231-239

Brothers N, Gales R, Hedd A, Robertson G (1998) Foraging movements of the shy albatross Diomedea cauta breeding in Australia: implications for interactions with longline fisheries. Ibis 140:446-457

Cooper J, Croxall JP, Rivera KS (2001) Off the hook? Initiatives to reduce seabird bycatch in longline fisheries. In: Melvin EF, Parrish JK (eds) Seabird bycatch: trends, roadblocks and solution. Proc Int Symp. AK-SG-01-01, University of Alaska Sea Grant, Fairbanks, p 9-32

Garthe S, Grémillet D, Furness RW (1999) At-sea-activity and foraging efficiency in chick-rearing northern gannets Sula bassana: a case study in Shetland. Mar Ecol Prog Ser 185: 93-99

Guinet C, Koudil M, Bost CA, Durbec JP, Georges JY, Mouchot MC, Jouventin P (1997) Foraging behaviour of satellite-tracked king penguins in relation to sea-surface temperatures obtained by satellite telemetry at Crozet Archipelago, a study during three austral summers. Mar Ecol Prog Ser 150:11-20

Harris G, Nilsson C, Clemenston L, Thomas D (1987) The water masses of the East Coast of Tasmania: seasonal and interannual variability and the influence on phytoplankton biomass and productivity. Aust J Mar Freshw Res 38:569-590

Hedd A (1998) Foraging ecology of shy albatross breeding in Australia: implications for interactions with fisheries. PhD thesis, University of Tasmania, Hobart

Hedd A, Gales R (2001) The diet of shy albatross Thalassarche cauta at Albatross Island, Tasmania. J Zool (in press)

Hedd A, Gales R, Brothers N, Robertson G (1997) Diving behaviour of the shy albatross Diomedea cauta in Tasmania: initial findings and dive recorder assessment. Ibis 139: $452-460$

Hedd A, Gales R, Brothers N (1998) Reliability of morphometric measures for determining the sex of adult and fledgling-aged shy albatross, Diomedea cauta cauta, in Australia. Wild Res 25:69-79

Hull CL, Hindell MA, Michael K (1997) Foraging zones of royal penguins during the breeding season, and their association with oceanographic features. Mar Ecol Prog Ser 153:217-228

Hunt GL, Croxall JP, Veit RR (1998) Foraging ecology of marine birds: Selection of foraging habitat by individuals and populations. In: Adams NJ, Slotow RH (eds) Proc 22 Int Ornithol Congr, Durban. Ostrich 69:105 
Irons DB (1998) Foraging area fidelity of individual seabirds in relation to tidal cycles and flock feeding. Ecology 79(2): 647-655

Prince PA, Croxall JP, Trathnan PN, Wood AG (1998) The pelagic distribution of South Georgia albatross and their relationship with fisheries. In: Robertson G, Gales R (eds) Albatross biology and conservation. Surrey Beatty \& Sons, Chipping Norton, Australia, p 137-167

Salamolard M, Weimerskirch H (1993) Relationship between foraging effort and energy requirement throughout the breeding season in the wandering albatross. Funct Ecol 7: 643-652

Wanless S, Harris MP, Morris JA (1991) Foraging range and feeding locations of shags Phalacrocorax aristotelis during chick rearing. Ibis 133:30-36

Waugh SM, Weimerskirch H, Cherel Y, Shankar U, Prince PA, Sagar PM (1999) Exploitation of the marine environment by two sympatric albatross in the Pacific Southern Ocean. Mar Ecol Prog Ser 177:243-254

Weavers BW (1992) Seasonal foraging ranges and travels at sea of little blue penguins Eudyptula minor, determined by radiotracking. Emu 91:302-207

Weimerskirch H (1998) Foraging strategies of Indian Ocean albatross and their relationships with fisheries. In: Robertson G, Gales R (eds) Albatross biology and conservation. Surrey Beatty \& Sons, Chipping Norton, Australia, p 168-179

Weimerskirch H, Robertson G (1994) Satellite tracking of light-mantled sooty albatross. Polar Biol 14:123-126

Weimerskirch H, Salamolard M, Sarrazin F, Jouventin P (1993) Foraging strategy of wandering albatross through the breeding season: A study using satellite telemetry. Auk 110(2): 325-342

Editorial responsibility: Otto Kinne (Editor),

Oldendorf/Luhe, Germany
Weimerskirch H, Doncaster CP, Cuenot-Chaillet F (1994) Pelagic seabirds and the marine environment: foraging patterns of wandering albatross in relation to prey availability and distribution. Proc R Soc Lond B 255:91-97

Weimerskirch H, Cherel Y, Cuenot-Chaillet F, Ridoux V (1997a) Alternative foraging strategies and resource allocation by male and female wandering albatross. Ecology 78(7):2051-2063

Weimerskirch H, Mougey T, Hindermeyer X (1997b) Foraging and provisioning strategies of black-browed albatross in relation to the requirements of the chick: natural variation and experimental study. Behav Ecol 8(6):635-643

Weimerskirch H, Wilson RP, Lys P (1997c) Activity pattern of foraging in the wandering albatross: a marine predator with two modes of prey searching. Mar Ecol Prog Ser 151: 245-254

Weimerskirch H, Guionnet T, Martin J, Shaffer SA, Costa DP (2000) Fast and fuel-efficient? Optimal use of wind by flying albatross. Proc R Soc Lond B 267:1869-1874

Williams H, Pullen G (1993) Schooling behaviour of jack mackerel Trachurus declivis (Jenyns) observed in the Tasmanian purse seine fishery. Aust J Mar Freshw Res 44: 577-587

Wilson RP, Pütz K, Peters G, Culik B, Scolaro JA, Charrassin JB, Ropert-Coudert Y (1997) Long-term attachment of transmitting and other recording devices to penguins and other seabirds. Wildl Soc Bull 17: 77-79

Wood AG, Naef-Daenzer B, Prince PA, Croxall JP (2000) Quantifying habitat use in satellite-tracked pelagic seabirds: application of Kernel estimation to albatross locations. J Avian Biol 31:278-286

Submitted: September 11, 2000; Accepted: January 25, 2001 Proofs received from author(s): December 7, 2001 